
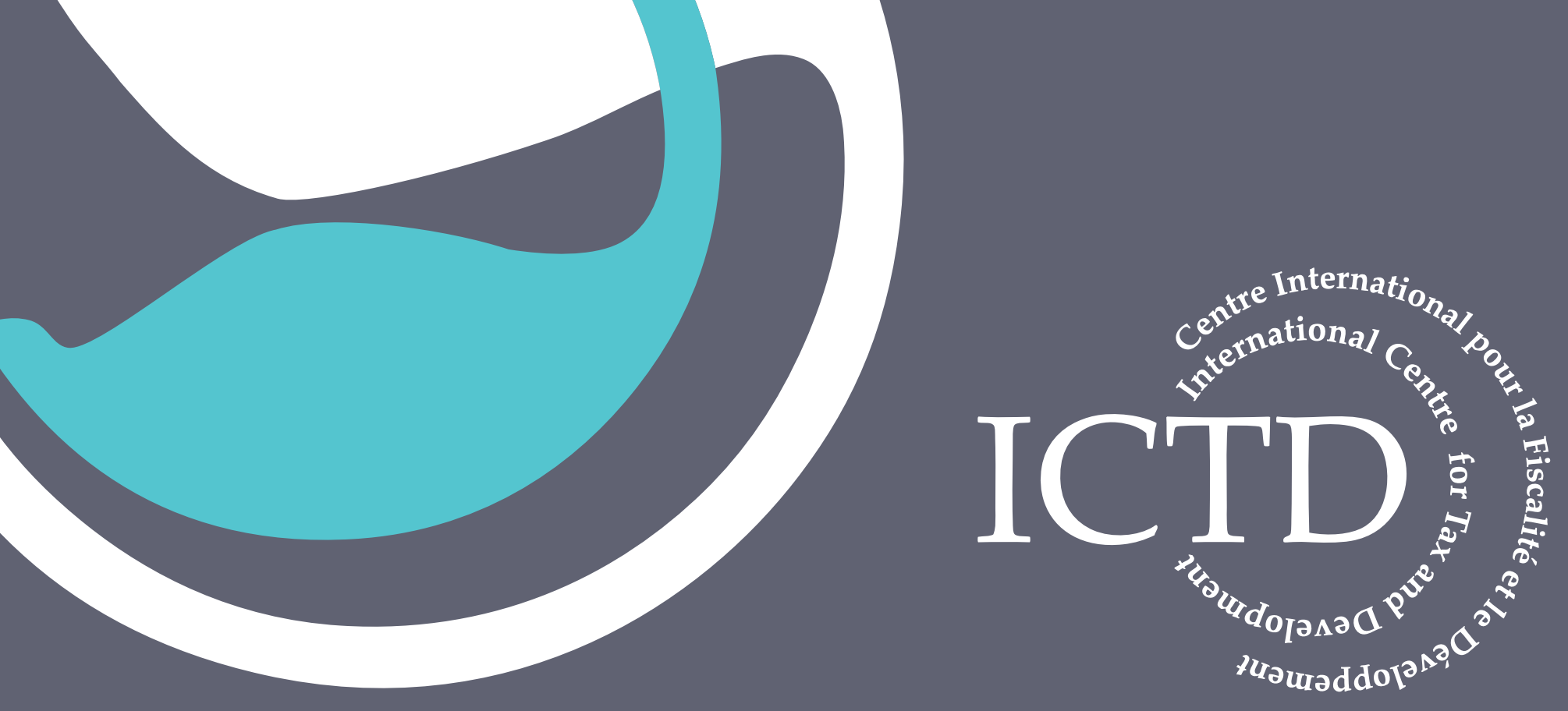

Working Paper 54

\title{
Tax Base Erosion and Profit Shifting in Affrica - Part 1: Africa's Response to the OECD BEPS Action Plan
}

Annet Wanyana Oguttu June 2016 
ICTD Working Paper 54

Tax Base Erosion and Profit Shifting in Africa - Part 1: Africa's Response to the OECD BEPS Action Plan

Annet Wanyana Oguttu

June 2016 
Tax Base Erosion and Profit Shifting in Africa - Part 1: Africa's Response to the OECD BEPS Action Plan Annet Wanyana Oguttu

ICTD Working Paper 54

First published by the Institute of Development Studies in June 2016

(C) Institute of Development Studies 2016

ISBN: 978-1-78118-297-0

A catalogue record for this publication is available from the British Library.

All rights reserved. Reproduction, copy, transmission, or translation of any part of this publication may

be made only under the following conditions:

- with the prior permission of the publisher; or

- with a licence from the Copyright Licensing Agency Ltd., 90 Tottenham Court Road, London W1P 9HE, UK,

or from another national licensing agency; or

- under the terms set out below.

This publication is copyright, but may be reproduced by any method without fee for teaching or nonprofit purposes, but not for resale. Formal permission is required for all such uses, but normally will be granted immediately. For copying in any other circumstances, or for reuse in other publications, or for translation or adaptation, prior written permission must be obtained from the publisher and a fee may be payable.

Available from:

The International Centre for Tax and Development

at the Institute of Development Studies,

Brighton BN1 9RE, UK

Tel: +44 (0) 1273606261 Fax: +44 (0) 1273621202

E-mail: info@ictd.ac.uk

Web: www.ictd/en/publications

IDS is a charitable company limited by guarantee and registered in England (No. 877338) 


\title{
Tax Base Erosion and Profit Shifting in Africa - Part 1: Africa's Response to the OECD BEPS Action Plan ${ }^{1}$
}

\author{
Annet Wanyana Oguttu
}

\section{Summary}

This paper considers what Africa's response should be to the OECD's base erosion and profit shifting (BEPS) project. The paper acknowledges that BEPS concerns for developing countries (such as those in Africa) may not necessarily be the same as those for developed countries. The author first explains the concepts of tax avoidance and tax planning, to describe the background to BEPS. An explanation is given of the causes of BEPS, the challenges BEPS poses to corporate tax systems, the importance of corporate taxes in Africa, and the factors that exacerbate BEPS in Africa. The paper also differentiates BEPS from the notion of illicit financial flows - a matter that is causing a lot of confusion to the general public in understanding BEPS issues, and to finding solutions to the problem of capital flight from Africa. Thereafter the author addresses the relevance of the OECD BEPS Project to Africa, the international initiatives that could benefit Africa in curtailing BEPS, and what Africa's response should be.

Keywords: base erosion and profit shifting; double non-taxation; domestic revenue mobilisation; harmful tax practices; illicit financial flows; international tax cooperation; tax avoidance; tax havens; tax morality; tax planning; tax treaties.

Annet Wanyana Oguttu is a Professor of tax law in the Department of Mercantile Law, College of Law, at the University of South Africa. 


\section{Contents}

Summary 3

Acronyms

Introduction 6

1 Understanding the concepts of tax avoidance, tax planning and tax mitigation 6

2 Overview of previous international measures to curtail BEPS 9

$3 \quad$ The OECD BEPS project $\quad 10$

$4 \quad$ Are corporate taxes still relevant today? 10

4.1 The importance of corporate income taxes in Africa 11

4.2 The importance of corporate taxation for domestic resource
mobilisation to ensure sustainable development in Africa

$5 \quad$ BEPS and perspectives on capital flight in Africa: distinguishing licit and illicit financial flows $\quad 13$

$\begin{array}{lll}6 & \text { BEPS in Africa } & 17\end{array}$

$7 \quad$ Factors that exacerbate BEPS in Africa 18

7.1 Lack of relevant international tax laws in place, or clear

7.2 Tax treaty negotiation dynamics that contribute to BEPS 18

$\begin{array}{ll}7.3 & \text { Limited tax administrative capacity } \\ \end{array}$

8 The relevance of the OECD BEPS project to Africa 20

$9 \quad$ How should Africa respond to the OECD BEPS Action Plan? 21

10 Initiatives in Africa responding to the OECD BEPS agenda 22

10.1 Initiatives by regional bodies 22

10.2 BEPS initiatives at national level 23

11 International initiatives that African countries should embrace to improve their tax systems and administrative capacity $\quad 24$

11.1 OECD initiatives on BEPS that can benefit Africa 24

11.2 G20 initiatives on BEPS in Africa 24

$\begin{array}{ll}11.3 & \text { UN initiatives in Africa } \\ \end{array}$

12 Addressing the OECD BEPS Action Plan from an African perspective 26

13 Concluding remarks $\quad 27$

$\begin{array}{lr}\text { References } & 29\end{array}$ 


\section{Acronyms}

$\begin{array}{ll}\text { ATAF } & \text { African Tax Administration Forum } \\ \text { BEPS } & \text { Base Erosion and Profit Shifting } \\ \text { DRM } & \text { Domestic Revenue Mobilisation } \\ \text { EU } & \text { European Union } \\ \text { IMF } & \text { International Monetary Fund } \\ \text { LIC } & \text { Low-income countries } \\ \text { MNE } & \text { Multinational enterprise } \\ \text { OECD } & \text { Organisation for Economic Co-operation and Development }\end{array}$




\section{Introduction}

Base erosion and profit shifting (BEPS) refers to tax avoidance by multinational enterprises (MNEs), which make use of gaps in the interaction of different tax systems to artificially reduce taxable income or to shift profits to low-tax jurisdictions in which little or no economic activity is performed (OECD 2013a). Curtailing BEPS and preserving countries' tax bases has been a concern of the international community and national governments for decades. Over the last few years, budgetary deficits resulting from the $2007 / 2008$ global financial crisis brought international concern about curtailing BEPS to the forefront (McKibbin 2010; Shah 2010), prompting the Organisation for Economic Cooperation and Development (OECD) to issue a report in 2013 in which it noted that 'BEPS constitutes a serious risk to tax revenues, tax sovereignty and tax fairness for OECD member countries and non-members alike' (OECD 2013a: 5). The OECD notes that what is at stake is the international corporate tax system. Consequently it came up with a 15-point BEPS Action Plan, which is intended to ensure that profits are taxed where the economic activities generating those profits are performed, and where value is created. ${ }^{2}$

This paper acknowledges that developing countries (such as those in Africa) may not necessarily have the same concerns about BEPS as developed countries. Part 1 of the paper (this part) addresses what Africa's response should be to the OECD BEPS Action Plan; Part 2 (forthcoming) will provide a critical analysis of the BEPS Action Plan from an African perspective. In Part 1, the author first explains the concepts of tax avoidance and tax planning with reference to international case law, which is of persuasive value in most African countries or forms part of the common law of such countries. An explanation is then given of the causes of BEPS, the challenges BEPS poses to corporate tax systems, the importance of corporate taxes in Africa, as well as the factors that exacerbate BEPS in Africa. Thereafter an explanation is given of the difference between BEPS and illicit financial flows - a matter that is causing a lot of confusion to the general public in understanding BEPS issues and finding solutions to the problem of capital flight from Africa. Based on this background, the author addresses the relevance of the OECD BEPS Action Plan for Africa, and what Africa's response should be.

\section{Understanding the concepts of tax avoidance, tax planning and tax mitigation}

To understand why countries have to curtail BEPS, it is first important to explain the freedom that taxpayers have to avoid taxes legally. Tax avoidance can be prevented through anti-taxavoidance provisions in domestic tax laws, double-tax treaties, and through countries adhering to international initiatives and recommendations against tax avoidance, such as those in the OECD 15-point BEPS Action Plan.

\footnotetext{
The OECD's 15-point Action Plan (discussed in detail in Part 2 of this paper from the perspective of African countries) is as follows: Action Plan 1: Address the Tax Challenges of the Digital Economy; Action Plan 2: Neutralise the Effects of Hybrid Mismatch Arrangements; Action Plan 3: Strengthen Controlled Foreign Companies Rules; Action Plan 4: Limit Base Erosion via Interest Deductions and Other Financial Payments; Action Plan 5: Counter Harmful Tax Practices More Effectively, Taking into Account Transparency and Substance; Action Plan 6: Prevent Treaty Abuse; Action Plan 7: Prevent the Artificial Avoidance of PE Status; Action Plan 8: Assure that Transfer Pricing Outcomes are in Line With Value Creation with respect to Intangibles; Action Plan 9: Assure that Transfer Pricing Outcomes are in Line With Value Creation with respect to Risks and Capital; Action Plan 10: Assure that Transfer Pricing Outcomes are in Line With Value Creation with respect to Other High-Risk Transactions; Action Plan 11: Establish Methodologies to Collect and Analyse Data on BEPS and the Actions to Address It; Action Plan 12: Require Taxpayers to Disclose Their Aggressive Tax Planning Arrangements; Action Plan 13: Re-examine Transfer Pricing Documentation; Action Plan 14: Make Dispute Resolution Mechanisms More Effective; Action Plan 15: Develop a Multilateral Instrument.
} 
Tax avoidance has to be distinguished from tax evasion, which is illegal and entails noncompliance with the tax laws. Tax evasion includes activities (like the falsification of tax returns and books of account) that are deliberately undertaken by a taxpayer to illegally free himself from the tax that the law charges upon his income. Tax authorities normally resort to criminal prosecution to prevent tax evasion (Meyerowitz 2009; OECD 1987). Tax avoidance involves using legal methods to arrange one's affairs, so as to pay less tax. This is done by utilising loopholes in tax laws and exploiting them within legal parameters (Meyerowitz 2009; Olivier 1997; Rapakko 1989). Since tax avoidance is legal, it can only be prevented if the legislature amends the law and prohibits the practice in question. It is in this regard that the courts have historically held the view that no legal obligation rests upon a taxpayer to pay higher taxes than he is legally bound to under the taxing Act, and that a taxpayer is not prevented from entering into a genuine, or bona fide, transaction which, when carried out, has the effect of avoiding or reducing liability to tax. As early as 1928, the UK court (whose decisions are of persuasive value in most countries previously colonised by the UK) held in the case of Levene $v I R C{ }^{3}$ that:

It is trite law that His Majesty's subjects are free, if they can, to make their own arrangements so that their cases may fall outside the scope of the taxing Acts. They incur no legal penalties, and, strictly speaking, no moral censure if, having considered the lines drawn by the legislature for the imposition of taxes, they make it their business to walk outside them.

Such arrangements by taxpayers to reduce their tax liability are normally referred to as tax planning or tax mitigation. In CIR $v$ Challenge Corporation Ltd, it was explained that Income tax is mitigated by a taxpayer who reduces his income or incurs expenditure in circumstances which reduce his assessable income or entitle him to reduction in his tax liability'. ${ }^{4}$ In CIR $v$ Willoughby, the court held that the hallmark of tax mitigation is that the taxpayer takes advantage of a fiscally-attractive option afforded to him by the tax legislation, and genuinely suffers the economic consequences that parliament intended to be suffered by those taking advantage of the option. ${ }^{5}$

\section{Tax avoidance and tax morality}

Historically, the courts have held that there is no morality regarding paying taxes. This was confirmed by Lord President Clyde in the UK case of Ayrshire Pullman Motors Services and $D M$ Ritchie $v I R C,{ }^{6}$ where it was held that:

No man in this country is under the smallest obligation, moral or otherwise, to arrange his legal relations to his business or to his property so as to enable the Inland Revenue to put the largest possible shovel into his stores. The Inland Revenue is not slow - and quite rightly - to take advantage, which is open to it under the taxing Statutes for the purpose of depleting the taxpayer's pocket. The taxpayer is in the like manner, entitled to be astute to prevent, so far as he honestly can, the depletion of his means by the Revenue.

This was confirmed by Lord Tomlin in the celebrated case of ICR v Duke of Westminster, ${ }^{7}$ where it was held that:

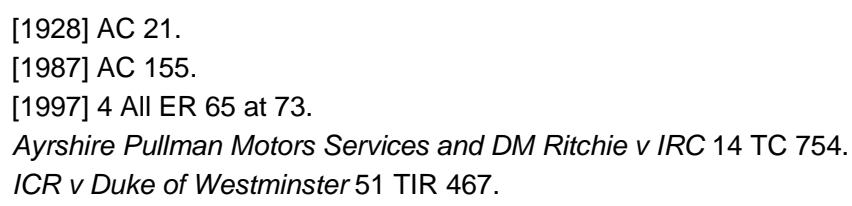


Every man is entitled if he can to order his affairs so that the tax attaching under the appropriate Act is less than it otherwise would be. If he succeeds in ordering them so as to secure this result, then, however unappreciative the Commissioner of Inland Revenue or his fellow taxpayers may be of his ingenuity, he cannot be compelled to pay an increased tax.

Even though tax avoidance is not illegal, over the years it has been frowned on by the courts and tax authorities as the resultant loss of tax revenue has the effect of limiting any government's ability to pursue its economic and social objectives (Brooks and Head 1997). Indeed, the morality of tax avoidance was questioned years back in cases such as $R e$ Weston's Settlements, in which Lord Denning made a characteristically terse admonition that 'the avoidance of tax may be lawful, but it is not yet a virtue'. ${ }^{8}$ In CIR v McGuckian, Lord Steyn remarked that the Duke of Westminster notion that a taxpayer is free to arrange his financial affairs as he thinks fit, had 'ceased to be canonical' as to the consequences of a tax avoidance scheme. ${ }^{9}$ In the New Zealand case of Elmiger $v$ CIR it was held that the:

Ingenious legal devices contrived to enable individual taxpayers to minimise or avoid their tax liabilities are often not merely sterile or unproductive in themselves (except perhaps in respect of their tax advantages for the taxpayer concerned), but that they have social consequences which are contrary to the general public interest. ${ }^{10}$

The House of Lords itself recognised the limits of the decision in the Duke of Westminster case. In IRC v Burmah Oil Co Ltd, Lord Tomlin pronounced that the Duke of Westminster case 'tells us little or nothing as to what methods of ordering one's affairs will be recognised by the courts as effective to lessen the tax that would otherwise attach to them if business transactions were conducted in a straight-forward way'. ${ }^{11}$ Consequently, over the years some countries have tried to make a distinction between proper tax planning, which is concerned with the organisation of a taxpayer's affairs so that they give rise to the minimum tax liability within the law, and those instances where taxpayers resort to artificial arrangements that have little or no actual economic impact upon the taxpayer, and are just designed to manipulate tax laws in order to achieve results that conflict with or defeat the intention of parliament. In Australia, for instance, the 1999 Report on Business Taxation, refers to a form of tax avoidance that is essentially a misuse or abuse of the law, and is driven by the exploitation of structural loopholes in the law to achieve tax outcomes that were not intended by parliament. It includes the manipulation of the law, and a focus on form and legal effect rather than substance (Australian Government 1999). In South Africa, the notion of 'impermissible tax avoidance' is used to refer to certain tax avoidance practices that extend beyond what is legally acceptable, ${ }^{12}$ and often involves taxpayers concealing their assets and income - keeping them outside their domestic tax jurisdiction, in low-tax and tax-haven jurisdictions. ${ }^{13}$ This concealment can take them over the dividing line between tax evasion and tax avoidance.

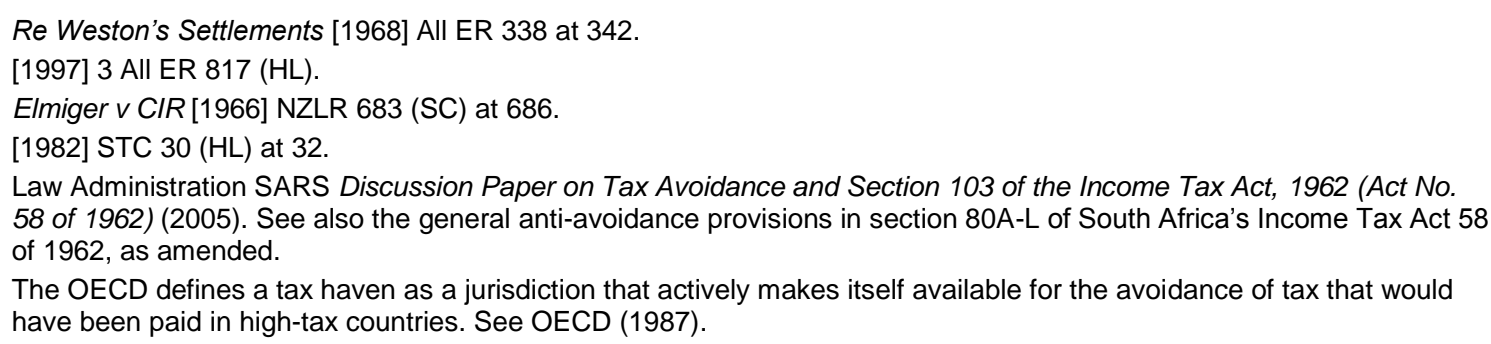




\section{Overview of previous international measures to curtail BEPS}

To reduce their global tax exposure, MNEs have increasingly employed global tax avoidance strategies to maximise profits, and their links with any country with a favourable tax climate have become much stronger. In response countries have enacted anti-avoidance legislation, but taxpayers are usually a step ahead. The cycle of continuous amendments to cover loopholes in the legislation has made most countries' corporate income tax provisions more complex, and yet this has not prevented well-advised taxpayers from aggressively avoiding domestic taxes by keeping their income in low-tax jurisdictions.

For decades the OECD failed to acknowledge that its member counties had dealings with tax havens, and that they had lent credibility to many tax havens. ${ }^{14}$ OECD member countries also failed to acknowledge that they benefited from their involvement with tax havens (Stikeman 2002). As the growth of tax havens continued to be a major cause of the depletion of countries' tax bases, from the early 1990s the international community began to take some measures to stifle their development. The European Union (EU), for instance, issued a report containing recommendations on company taxation in Europe that would prevent residents of member countries from transferring investments to other member countries that levied lower taxes. Since then the EU has issued various directives to prevent the depletion of its member countries' tax bases (Kesti 2013). In 1997, the EU Council of Economic and Financial Ministers agreed on a package of measures to tackle harmful tax competition in order to help reduce distortions in the single market and to prevent excessive loss of tax revenue (Bennet 2001). The measures included a Code of Conduct on business taxation. ${ }^{15}$ Subsequently a group of representatives of EU member states, called the Primarolo group, was set up to gather information on and assess any national tax measures that might fall foul of the Code (Terra and Wattel 2005: 284). In 1998 the Primarolo group came up with a report that blacklisted harmful national tax measures (Terra and Wattel 2005).

In 1998 the OECD issued a Report on Harmful Tax Competition (OECD 1998), in which it pointed out that tax-haven jurisdictions and harmful preferential tax regimes have harmful tax practices in place ${ }^{16}$ which may lead to the depletion of other countries' tax bases and distort financial and investment flows among countries. ${ }^{17}$ Further, these harmful tax practices undermine the integrity and fairness of tax systems; they discourage compliance by all taxpayers; cause undesirable shifts of the tax burden to less mobile tax bases such as labour, property and consumption; and they increase the administrative costs and compliance burdens on tax authorities and taxpayers (Roper and Ware 2001). In order to counter these harmful tax practices, the OECD recommended certain anti-avoidance measures that countries needed to adopt in order to enhance the effectiveness of their domestic legislation in curbing offshore tax avoidance (OECD 1998). The G8/G20 have, over the years, reinforced the initiatives of the EU and OECD in tackling harmful tax competition and obtaining information about transactions in tax havens and preferential tax regimes. ${ }^{18}$

\footnotetext{
$14 \quad$ Diamond and Diamond (2002) note that the UK has for years lent credibility to its overseas territories that have the status of British Crown dependencies. See Foreign and Commonwealth Office 'Partnership for Progress and Prosperity - British and Overseas Territories', available at

<http://www.fco.gov.uk/servlet/Front?pagename=OpenMarket/Xcelerate/ShowPage\&c=Page\&cid=1018028164839>, last accessed 18 May 2015.

15 The Code of Conduct is a political commitment, not a legally enforceable rule. See Bratton and McCahery (2001).

16 A harmful preferential tax regime can occur in both tax-haven and high-tax jurisdictions. Harmful tax regimes are characterised by having no or low effective tax rates on income, the regimes are ring-fenced, and there is a general lack of transparency and effective exchange of information with other countries. See OECD (1998).

OECD (1998); Spitz and Clarke (2002).

G8 Information Centre: The Birmingham Summit 'G7 Initiative on Harmful Tax Competition' (15-17 May 1988). Available at <http://www.g7.utoronto.ca/summit/1998 birmingham/harmfultax.html>, last accessed 3 July 2015.
} 
Despite the OECD's 1998 report on harmful tax completion (Diamond and Diamond 2002), there was no political will among the governments of rich economies to deal with their own harmful tax practices and preferential tax regimes. ${ }^{19}$ Instead the OECD, under its Global Forum, placed emphasis on ensuring that tax havens implement its standards of transparency and exchange of information for tax purposes, and that they exchange information about investments by other country residents in those jurisdictions (OECD 2007a).

\section{The OECD BEPS project}

In the aftermath of the $2007 / 2008$ global financial crisis, concerns about MNEs not paying their fair share of taxes were again brought to the forefront. This was engineered by nongovernmental organisations (NGOs) like Christian Aid and the Tax Justice Network, which voiced public concern about companies paying little or no corporation tax in the countries in which they do business (Christian Aid 2008; Tax Justice Network n.d). As a result, at the 2012 G20 summit in Mexico the national leaders explicitly referred to the need to prevent BEPS. ${ }^{20}{ }^{21}$ At the behest of the G20, in February 2013 the OECD released its BEPS Report (OECD 2013a). Following the release of the BEPS report, there is now political will to address these concerns from governments and policymakers (Crivelli et al. 2015).

BEPS is enabled by the fact that the current international corporate taxation framework has not kept pace with the changing business environment (Crivelli et al. 2015). Domestic rules for international taxation and internationally agreed standards are still grounded in an economic environment characterised by a lower degree of economic integration across borders - rather than today's environment of global taxpayers, characterised by MNE companies that are placing importance on intellectual property as a value-driver, and the development of information and communication technologies. As businesses increasingly integrate across borders, the tax rules often remain uncoordinated: businesses come up with structures that are technically legal, but take advantage of asymmetries in domestic and international tax rules. The OECD notes that what is at stake is corporate income tax (OECD 2013b).

\section{Are corporate taxes still relevant today?}

Since its inception over a century ago, corporate income tax has brought various advantages to countries' tax systems. Corporate tax is an important backstop for personal income tax, and it can prevent excessive income shifting between labour income and capital income. Corporate taxes ensure tax on equity income earned by non-resident shareholders, which might otherwise escape taxation in the source country (OECD 2007b). Corporate taxes also

\footnotetext{
19 RS Avi-Yonah, 'Prepared Testimony of Reuven S. Avi-Yonah, Irwin I Cohn Professor of Law, University of Michigan Law School before the US Senate Permanent Subcommittee on Investigations, Hearing on Offshore Transactions' (1 August 2006). Available at

<http://hsgac.senate.gov/_files/STMAviYonahUafMI.pdf\#search=\%22Prepared\%20testimony\%20of20AviYonah\%20before\%20permanent\%20subcommitte\%20>, last accessed on 18 May 2015.

20 The G20 (Group of twenty) is an international forum for the governments and central bank governors from 20 major economies. The members include the EU and 19 countries: Argentina, Australia, Brazil, Canada, China, France, Germany, India, Indonesia, Italy, Japan, Mexico, Russia, Saudi Arabia, South Africa, South Korea, Turkey, the United Kingdom and the United States. The G20 was founded in 1999 with the aim of studying, reviewing and promoting highlevel discussion of policy issues pertaining to the promotion of international financial stability. For details see Wikipedia 'G20 Major Economies'; available at <http://en.wikipedia.org/wiki/G-20_major_economies>, accessed 8 May 2015. G20 Leaders' Declaration, Los Cabos Mexico (2012). Available at <http://g20mexico.org/images/stories/temp/G20_Leaders_Declaration_2012.pdf>, accessed 3 August 2013.
} 
provide a means of preventing the deferral of taxes by rich individuals who would be able to invest in foreign subsidiary companies and defer taxes indefinitely (until the corporation distributes dividends or when shares are sold) (Avi-Yonah 2015). Taxing corporate profits on an accrual basis, through the use of controlled foreign company legislation, ensures that individuals cannot use foreign subsidiaries as tax shelters. Corporate tax has also been used as an important vehicle to regulate corporate behaviour. It can be used as a disincentive for behaviour the legislator deems to be undesirable - for example, paying bribes or participating in boycotts; and it can be used as an incentive for desirable behaviour - for example, investment incentives, hiring incentives and clean energy incentives (Avi-Yonah 2015).

Despite the above some critics argue that corporate tax should be abolished, as it has become very complicated and ineffective due to tax avoidance strategies by MNEs encouraged by globalisation and technological advancements. The administrative costs of trying to make the corporate tax system work impose significant losses on the economies of many countries (Avi-Yonah 2015). It is thus contended that eliminating corporate taxes would not only reduce or eliminate the incentive to shift profits to low-tax jurisdictions, but would also eliminate all the time, effort and money that companies spend on tax avoidance. This would level the playing field for smaller domestic businesses, which typically cannot afford to hire lawyers and accountants to devise the tax avoidance strategies that give MNEs a potential competitive advantage. It is also argued that corporate taxes amount to an additional tax on income, and that the incidence of tax is ultimately borne by individuals: although taxes may be levied on corporations, it is ordinary people that pay the tax. Thus levying corporate taxes amounts to double taxation: the tax on investment in corporate stocks would have been already taxed when earned by the individual, and again when it is paid out in dividends or sold for a capital gain (Avi-Yonah 2015). The relative importance of corporate tax in developed countries has also been questioned. Across the OECD, corporate income tax raises, on average, revenue equivalent to 3 per cent of GDP, or 10 per cent of total tax revenue (Avi-Yonah 2015). KPMG data reveals that, due to tax competition between countries, global corporate tax rates have generally declined between 2006 and 2013;22 this raises questions about the importance of corporate taxes in light of the challenges discussed above.

\subsection{The importance of corporate income taxes in Africa}

Despite the above arguments, in Africa the corporate tax system is a very important source of revenue that must be retained (Avi-Yonah 2015). While in OECD countries corporate tax is relatively not an important source of revenue, this is not true in developing countries - where it generally amounts to over 25 per cent of total revenue. The average for Africa is 29 per cent of total revenue (Avi-Yonah 2015). It should also be noted that, unlike the case of developed countries that can derive reasonable amounts of revenue from individual income taxes and consumption taxes, in many developing countries domestic economic activity occurs informally, with businesses maintaining few books and records, so the ability of governments to raise revenue from individuals and consumption taxes is limited. For these countries, taxing companies is crucial - otherwise they would have to rely entirely on the regressive Value Added Tax. In Africa, corporate tax from MNEs represents a major portion of the revenue tax base, since the domestic corporate tax base is often quite limited (Durst 2014). For developing countries concern about double taxation caused by corporate taxes is not that serious, as some of the bearers of the tax burden (e.g. the providers of capital and consumers) are non-resident. It should also be noted that in many African countries most corporate tax is levied on corporate profits derived from rents for the exploitation of countryspecific resources, which makes it an efficient tax for a country to impose (Avi-Yonah 2015).

KPMG Corporate Tax Rates Table, available at <http:/www.kpmg.com/global/en/services/tax/tax-tools-andresources/pages/corporate-tax-rates-table.aspx>, accessed 24 May 2015. 
From the above it is clear that developing countries, such as those in Africa, have much more at stake in an effective international tax system because their development depends on it. This is confirmed by the 2015 IMF Spillovers Working Paper, which suggests that spillover effects on the tax base are substantially larger in developing than in advanced countries, which implies a likely loss of revenue from BEPS that is substantially larger for them (Crivelli et al. 2015). Spillover effects are essentially the impact of one country's tax policy on the tax bases of other countries (this could be either through investments or shifting of profits) (Crivelli et al. 2015). For developing countries, even a single international tax case can involve very significant amounts of revenue (IMF 2014). These sums may be small relative to total tax revenue in sizeable advanced economies, but are large for the developing countries that are increasingly involved in such cases (IMF 2014). Thus the need for African countries to be associated with the OECD BEPS project, because it has the potential to put an end to tax avoidance by MNEs and so help to raise corporate tax revenue in African countries.

\subsection{The importance of corporate taxation for domestic resource mobilisation to ensure sustainable development in Africa}

At the UN Millennium Summit held on 6 September 2000 in New York, world leaders committed their nations to a new global partnership to reduce extreme poverty by 2015 . They agreed the Millennium Development Goals, which focus on mobilising resources to address the major gaps in human development. ${ }^{23}$ Building upon the Millennium Development Goals, at the 2012 UN Conference on Sustainable Development in Rio de Janeiro world leaders launched a set of Sustainable Development Goals that would promote sustained and inclusive economic growth. ${ }^{24} 25$

For decades, many African countries have relied on aid from foreign donors to build economic growth and fund government expenditure. Even though foreign aid has made a significant contribution to development, it is not sufficient for African countries to achieve sustainable equitable growth and poverty reduction. This is especially so now that many traditional donors from Europe and the USA have limited budgets due to the recession caused by the 2007/2008 global financial crisis (Centre for Strategic and International Studies 2014). The volatility associated with outside funding has prompted African leaders to realise that external sources like foreign aid will be insufficient to meet the Millennium Development Goals and sustain progress beyond the 2015 target date (North-South Institute 2012). In the current global economic context, the development of African economies has to depend primarily on the efforts of African countries themselves - their ability to mobilise domestic resources from the public and private sectors to enhance Africa's development agenda (UNCTAD 2007). Domestic resources that are vital for state-building can be mobilised from both the public and private sectors. The public sector largely does this through taxation, non-tax and other forms of government revenue generation (North-South Institute 2012). Corporate taxes from MNEs, as explained above, are a large proportion of many African countries' tax bases (Durst 2014), and it is important to preserve this tax base - it has the potential to contribute greatly to domestic revenue mobilisation (DRM), which can play a major role in fostering long-term financing for sustainable development in Africa. It would also ensure that African countries are weaned off long-term aid dependency, to their own stable and predictable sources of revenue. African countries could then take ownership of their development policies and implement strategies that reflect their development

\footnotetext{
23 UN 'Millennium Summit' (6-8 September 2000). Available at

<http://www.un.org/en/events/pastevents/millennium_summit.shtml accessed 24 May 2015>. The Millennium Development Goals are to: eradicate extreme poverty and hunger; achieve universal primary education; promote gender equality and empower women; reduce child mortality; improve maternal health; combat HIV/AIDS, malaria and other diseases; ensure environmental sustainability; and develop a global partnership for development.

24 Rio +20 'United Nations Conference on Sustainable Development', available at <http://www.uncsd2012.org/>, accessed 25 May 2015.

25 UN Open Working Group proposal for Sustainable Development Goals, available at <https://sustainabledevelopment.un.org/sdgsproposal>, accessed 24 May 2015.
} 
priorities. This would facilitate effective fiscal planning - resources could be allocated to priority sectors, rather than being constrained by donor conditions that often dictate the sectors to which aid should flow. DRM would also foster government accountability to its taxpaying citizens, ensuring governments pay more attention to the demands of taxpaying citizens than is the case when they are heavily dependent on foreign aid.

Although in recent years there has been increased growth of DRM in many African countries - in sub-Saharan Africa DRM is estimated to constitute about 70 per cent of development finance, with the 30 per cent shortfall usually being filled by loans, aid or other forms of public finance - there are still enormous challenges facing DRM in sub-Saharan Africa. This is because the tax bases across much of Africa are very narrow, and the tax burden falls disproportionately on the small formal sector of the economy (North-South Institute 2012). In addition, the saving rate in most African countries is low, and institutional capacity to mobilise domestic resources is weak (Culpeper and Bhushan 2010). DRM is also hampered by the fact that many African countries grant tax incentives to foreign investors in order to encourage foreign investments; tax incentives have been noted to distort resource allocation leading to sub-optimal investment decisions that are harmful to long-term growth. Many African tax statutes also have various tax exemptions that are costly in terms of forgone revenue. The exemptions complicate tax systems, and open the door to political interference and corruption (Culpeper and Bhushan 2010). The limited tax reporting, low levels of tax education among the population, the general culture of non-tax compliance, weak capacity and inadequate resourcing of most tax administrations, as well as the lack of political will to insulate tax administration from political incursions, all contribute to low DRM. Tax officials often have great discretionary power, which leads to pervasive corruption and a lack of transparency that inhibit citizens' willingness to comply with tax laws. The fact that many African countries levy high taxes, coupled with incomprehensible and complex tax legislation in some countries, also encourages tax evasion and avoidance, undermining collection. Over and above the above factors, the main stumbling block to DRM in Africa is capital flight - as discussed below.

\section{BEPS and perspectives on capital flight in Africa: distinguishing licit and illicit financial flows}

From a legal perspective, it is important to clarify that the problem of capital flight in Africa falls under two main categories: licit - legal - capital flight, and illicit capital flight. Global Financial Integrity notes that 'Illicit financial flows are by far the most damaging economic problem facing Africa', and it is considered the 'most pernicious global development challenge of our time' (Baker 2005: 25). There is, however, no universally-agreed definition of illicit financial flows, and their boundaries are disputed. The term generally implies the movement of money in a way that contravenes the laws or regulations of a country. Such movements of money can be a product of illegal activities, such as tax evasion, organised crime, customs fraud, money laundering, terrorist financing and bribery. However, some controversial definitions include in illicit financial flows certain corporate tax-avoiding practices, such as BEPS, which are legal (Payne et al. 2014).

The OECD acknowledges that although there are cases of illegal abuses (which are the exception rather than the rule), MNEs engaged in BEPS comply with the legal requirements of the countries involved, in that they use legal methods to circumvent the application of a country's tax law. The exceptions could (as explained above) cover cases where taxpayers 
secretly conceal their foreign investments from their domestic tax authorities, blurring the dividing line between illegal tax evasion and tax avoidance. In the past, taxpayers made use of banking secrecy rules that operated in tax-haven jurisdictions and some low-tax countries, by which the ownership of assets or income or their business transactions were to be kept from the knowledge of the tax authorities (United Nations 1984). It is these activities, which are difficult to monitor due to the secrecy involved, that have prompted some civil society organisations to equate the resultant BEPS to illicit financial flows. It is, however, worth noting that Global Financial Integrity stated in its report Illicit Financial Flows from Developing Countries Between 2003 and 2012 (2014b) that capital flight includes both licit and illicit capital, noting that licit capital flight is recorded and tracked, significantly lowering the probability that it has a corrupt or criminal source. In contrast, illicit financial flows are by nature unrecorded, and cannot be used as public funds or private investment capital in their country of origin (Kar and Spanjers 2014: para 2).

Nevertheless, over the last few years public confusion on these matters has been created by a strong drive from some civil society organisations (e.g. Oxfam, Global Financial Integrity and the Tax Justice Network) that have come up with estimates to provide a proxy for BEPS behaviour by equating BEPS to illicit finical flows. There are, however, very few studies that have made a proper evaluation of the extent of illicit capital transfers from Africa. Part of the reason for this is the unavailability of data and the lack of transparency by the entities involved in these transactions. The main estimates in this regard have been produced by studies carried out by Global Financial Integrity, which estimate that tax and illicit capital flight from Africa is between $\$ 50$ billion and $\$ 80$ billion per annum, and in some cases revenue lost exceeds the level of aid received. ${ }^{26}$ Furthermore, that over a thirty-nine-year period Africa lost a staggering $\$ 854$ billion in cumulative capital flight. Even though there are significant regional differences, the overwhelming bulk of capital flight through illicit means was from sub-Saharan African countries. Western African countries, particularly those endowed with natural resources, also had very high amounts of illicit transfers (Thabo Mbeki Foundation n.d.). Illicit financial flows from Africa are said to have spiked from 2000 to 2008 relative to earlier decades, mostly driven by increased average outflows from the western, central and southern regions due to rising income levels fuelled by the global price increase of commodities (Thabo Mbeki Foundation n.d.). Global Financial Integrity notes that 'these illicit outflows sapped 5.7 per cent of GDP from sub-Saharan Africa over the last decade, more than any other region in the developing world (Thabo Mbeki Foundation n.d.). Perhaps most alarmingly, 'outflows from sub-Saharan Africa were found to be growing at an average inflation-adjusted rate of more than 20 per cent per year, underscoring the urgency with which policymakers should address illicit financial flows' (Global Financial Integrity 2014a: 1).

In a 2013 joint report by the African Development Bank and Global Financial Integrity, it is reported that 'the problem with illicit outflows from Africa is so severe that after adjusting all recorded flows of money to and from the continent (e.g. debt, investment, exports, imports, foreign aid, remittances) illicit financial outflows from Africa between 1980 and 2009 meant that Africa was a net creditor to the rest of the world by up to US\$1.4 trillion' (African Development Bank and Global Financial Integrity 2013: 2). Global Financial Integrity reports that South Africa alone has lost out on billions in tax revenue in the past decade as large corporations, wealthy individuals and criminal syndicates slipped nearly R1 trillion out of the country. Global Financial Integrity notes that South Africa suffered 'illicit financial flows' totalling more than $\$ 122$ billion between 2003 and the end of 2012 (Kar and Spanjers 2014; Times Live 2015). Furthermore, in 2012 alone \$29.1 billion left the country under the radar. As a proportion of the size of the economy, South Africa's illicit financial flows came to 7.6 per cent, nearly twice the average for developing countries.

26 As reported by Thabo Mbeki Foundation (n.d); see also ATAF (n.d.). 
Several economic models have been used to provide estimates of illicit financial flows and capital flight. The most widely-used model subtracts the total funds actually used by a country from the total funds entering that country. The inflow of funds is defined as any increase in foreign debt plus incoming foreign direct investment. Funds used are those necessary to finance the deficit in the current account (one of the components of the balance of payments) and to add to the country's official reserves. If there are more funds coming in than funds being used, the resulting shortfall is considered to be illicit flows (Kar and Cartwright-Smith 2008). ${ }^{27}$ For example, a study carried out by Ndikumana and Boyce (which came up with almost similar conclusions as those above) estimates that the total real capital flight from Africa from 1970-2004 amounted to \$444 billion (Ndikumana and Boyce 2010). This is equivalent to 104 per cent of Africa's exports and 124 per cent of Africa's imports (2007 values). The study further found that annual capital flight amounted to $\$ 49$ billion/year averaged over 2000-2008, which would fill 54 per cent of Africa's infrastructure financing gap (Thabo Mbeki Foundation n.d.).

With MNEs not paying their fair share of taxes in the countries they operate in, many governments are also contemplating the vexed issue of determining and measuring the extent of tax evasion and/or avoidance. ${ }^{28}$ Although the question of how much revenue is lost due to profit shifting is interesting for the public, it has been noted that there are methodological flaws underlying the estimates which prevent them from being very reliable. For instance, a Report by the Oxford University Centre for Business Taxation notes that some estimates approximate taxable income or tax payments in absence of tax avoidance by using profits from financial accounts multiplied by the statutory tax rate to capture differences between financial and tax accounting (Oxford University Centre for Business Taxation 2012). Other estimates approximate foreign capital stocks multiplied by a deemed return and an average tax rate without considering the role of tax incentives and tax base regulations (Fuest and Riedel 2010). Comparing taxable profits with these inadequate benchmarks reveals conceptual differences between the underlying statistics, rather than the scale of profit-shifting activity.

Even though African countries, like other developing countries, face significant challenges that impact on revenue collection as a result of illicit financial flows, equating BEPS to illicit financial flows is not correct in terms of international tax law norms. As indicated above, BEPS is a result of perceived weakness in international tax laws, as well as lack of administrative capacity to fully assess and audit international tax risks that are exploited by MNEs. Illicit financial flows are a result of a wide range of illegal flows of money, such as from organised crimes, money laundering, terrorist financing, bribery and customs fraud. Equating BEPS to illicit financial flows fosters confusion in understanding international tax principles, and in finding solutions to the problem of capital flight.

Although all financial flows (whether illicit or licit) have an impact on revenue collection, the legal solutions to resolving licit BEPS issues are different from those required to resolve illicit financial flows. Curtailing BEPS requires reforming the international tax system and coming up with anti-tax avoidance measures - which is what the OECD BEPS agenda is all about whereas curtailing illicit financial flows requires criminal sanctions. It should also be noted that there is no one tax avoidance measure that can be used to effectively curtail all BEPS schemes. The transfer pricing legislation that is required to curtail transfer pricing schemes cannot be applied to curtail treaty abuse; neither can one apply the controlled foreign company rules that are used to prevent the deferral of taxes to curtail schemes involving excessive deductions of interest. This is why the BEPS Action Plan has various Action items,

\footnotetext{
See also Thabo Mbeki Foundation (n.d.).

This is exemplified by a recent UK poll which showed that $59 \%$ of the UK public thinks that tax avoidance is morally wrong. See Economia 'Majority says unacceptable to avoid tax' (2 March 2015), available at <http://economia.icaew.com/news/march-2015/majority-says-unacceptable-to-avoid-tax\#sthash.XUU2VtIW.dpuf>, accessed 18 May 2015
} 
requiring countries to come up with different anti-avoidance rules that can be applied to curtail the BEPS that arises from various tax avoidance schemes.

In the case of illicit financial flows, the very use of the term 'illicit' implies that the illegal nature of such activities calls for criminal action. Illegal tax evasion is a criminal matter, not a BEPS matter. Tax evasion has to be proved in terms of the relevant country's penal codes, as would be the case for any other criminal activity resulting in illegal movement of money. Illicit financial flows through trade mis-invoicing, which was estimated by Global Financial Integrity in 2012 to account for nearly 99 per cent of illicit financial outflows from Africa (Kar and Spanjers 2014), is not a BEPS matter, and should not be confused with the concept of transfer pricing - a BEPS matter. Trade mis-invoicing falls under the category of revenue laws that deal with customs. It is a customs fraud, which involves buyers and sellers presenting fraudulent documentation to customs officials. They falsify the value of their trade by under- or over-invoicing their trade documents to be less or more than the actual market value, in order to circumvent the payment of customs duties (Times Live 2015). The 2014 UNCTAD Trade and Development report notes that illicit flows of capital through developing countries due to trade miss-invoicing is one of the most pressing challenges facing policymakers, since it costs countries billions of dollars in revenue (UNCTAD 2014). The UNCTAD report recommends that in order to prevent trade mis-invoicing, governments need to resort to capital management measures, including capital controls (UNCTAD 2014).

There is no doubt that, as is the case with BEPS, international cooperation is required to address illicit financial flows. At the August 2014 US/Africa Leaders Summit, US President Obama expressed concern about illicit financial flows from Africa. This resulted in an agreement between the US and some African countries to form a partnership on curbing illicit financial flows from African economies. Commenting on this partnership, Global Financial Integrity cautioned that any effective partnership must address deficiencies in both the US and Africa that facilitate the haemorrhage of illicit capital from Africa. Global Financial Integrity noted that:

For every country losing money illicitly, there is another country absorbing it. Illicit financial outflows are facilitated by financial opacity in tax havens and in major economies like the United States ... While governance remains an issue for many African countries, structural deficiencies in the U.S. financial system are just as responsible for driving the outflow of illicit capital. This initiative cannot place the onus entirely on the shoulders of African governments. The burden for curtailing these illicit flows must be shared equally by policymakers in the U.S. and in Africa for this partnership to be effective.

(Global Financial Integrity 2014a: 2).

There is also no doubt that transparency, through exchange of information between countries, will play a major role in exposing both BEPS and illicit financial flows. However, equating illicit financial flows to BEPS under the current legal framework is a misconception of the law, and addressing BEPS under the umbrella of illicit financial flows is not in line with international tax law norms.

In the outcome document of the UN's 'Third International Conference on Financing for Development' held in Addis Ababa 13-16 July 2015, the Heads of State and Government and High Representatives affirmed as follows:

We will redouble efforts to substantially reduce illicit financial flows by 2030 , with a view to eventually eliminating them, including by combating tax evasion and corruption through strengthened national regulation and increased international cooperation. We will also reduce opportunities for tax avoidance, and consider inserting anti-abuse clauses in all tax treaties. We will enhance disclosure practices and transparency in 
both source and destination countries, including by seeking to ensure transparency in all financial transactions between Governments and companies to relevant tax authorities. We will make sure that all companies, including multinationals, pay taxes to the Governments of countries where economic activity occurs and value is created, in accordance with national and international laws and policies.

(United Nations 2015: para 23)

To help combat illicit flows, participants agreed to invite the IMF, World Bank and UN to assist both source and destination countries (United Nations 2015). They also agreed to 'identify, assess and act on money-laundering risks, including through effective implementation of the Financial Action Task Force standards on anti-money-

laundering/counter-terrorism financing'. They also encouraged 'information-sharing among financial institutions to mitigate the potential impact of the anti-money-laundering and combating the financing of terrorism standard on reducing access to financial services' (United Nations 2015: para 24). With respect to licit financial flows involving tax avoidance, the outcome document welcomed the work of the OECD Global Forum on Transparency and Exchange of Information for Tax Purposes, and the work of the OECD on base erosion and profit shifting (United Nations 2015).

\section{BEPS in Africa}

Concerns about BEPS are not new in Africa. Like other developing countries, for decades African countries have been victims of this phenomenon, with their residents shifting money to developed countries and tax-haven jurisdictions. The loss of tax revenue as a result of BEPS leads to critical under-funding of public investment that could help promote economic growth, and it impacts negatively on badly-needed finances to fund public infrastructure such as roads, hospitals and schools. BEPS undermines the integrity of the tax system. It discourages tax morality, and encourages a perception that the tax system is unfair. This, in turn, reduces voluntary compliance by all taxpayers. It also undermines competition, since MNEs have a competitive advantage over enterprises that operate at domestic level (especially small- and medium-size enterprises).

It has to be pointed out that there are some MNEs whose business transactions in Africa are generally legally acceptable. Such companies assert that their tax concerns in Africa are focused on core compliance rather than tax planning, given the increasing efforts of revenue officials to curtail tax avoidance. Furthermore, such companies contend that the relatively small size of African operations in certain sectors does not lend itself to tax planning projects that can have an overall impact on their global effective income tax rates. Nevertheless, African country tax officials deal with many cases of MNEs that are involved in tax avoidance schemes that are eroding their tax bases. There has also been circumstantial evidence of the same - for example, the famous SABMiller report by ActionAid, which exposed the tax dodged by SABMiller in Africa (particularly in Ghana) (ActionAid 2012). ActionAid explains that many of the company's local beer brands like Castle, Stone and Chibuku were invented in African countries like Ghana, South African and Zambia. These brands were sold by the London-based beer company SABMiller to its subsidiary in Netherlands to take advantage of Netherland's advantageous tax rules, which permit companies to pay low taxes on royalties (ActionAid 2012). Although there is circumstantial evidence, such as the above, that BEPS behaviour is widespread in Africa, it is difficult to reach solid conclusions about how much BEPS actually occurs. There is no accurate estimate of the amount of profits shifted (Fuest et al. 2013). 


\section{Factors that exacerbate BEPS in Africa}

\subsection{Lack of relevant international tax laws in place, or clear understanding of how these laws work}

Many African countries do not have proper international tax laws in place to counter BEPS. Historically, the reason behind this is that most African countries did not encourage investment aboard by their residents, as these countries enforced strict exchange controls. Many African countries had adopted a policy that the growth of their economies could best be achieved by encouraging domestic production - with domestically-owned firms producing goods and services for domestic consumption (Thuronyi 1998). Their tax systems prioritised the taxation of domestic income of resident taxpayers (Thuronyi 1998). This meant that the development of international tax laws in Africa lagged behind that of developed countries.

With the increasing internationalisation of economic relations, many African countries are now paying attention to international tax issues. This is especially so given that many African countries have large resource bases that are exploited by foreign investors (Thuronyi 1998). Despite the various geopolitical and infrastructural challenges that pose difficulties to doing business on the continent (Corey 2008), various countries are making progress in putting in place the right environment to encourage investors to enter their markets. This has happened to such an extent over the last decade that foreign investors have begun to recognise that 'Africa is the new frontier of the global economy' (Corey 2008). The OECD has also noted that 'Africa is the new emerging markets investment frontier' (Santiso 2007). As global capital starts flowing to frontier markets across Africa, governments will have to deal with the resultant tax schemes. ${ }^{29}$ This, coupled with the globalisation of the world economy, implies that African countries can no longer isolate their tax systems. The development of multinational enterprises, which have shifted their management structure from country-specific operating models to global models, implies that African countries cannot ignore the need to come up with the relevant international tax laws to address BEPS (OECD 2013b). The adoption of international tax rules also has the added advantage of increasing the capacity of a country to enforce taxation of the domestic income of residents, through provisions relating to the exchange of information on tax matters.

\subsection{Tax treaty negotiation dynamics that contribute to BEPS}

Double-tax treaties are an important aspect of international tax laws. However many African countries have signed few tax treaties, and some of those treaties were entered into mainly as a political gesture - not because there were significant capital flows from the developed countries concerned (OECD 2013b). Many African countries took the view that they did not need tax treaties, on the basis that signing treaties would result in the loss of taxing rights. It would mean giving up part of the revenue from source taxation, and being bound by restrictive bilateral treaty provisions (e.g. the provisions that require source countries to levy reduced withholding taxes on dividends and interest). However, over the last decade the attitude of many African countries to tax treaties has changed, as demonstrated by their expanding tax treaty network. The new policy shift is partly because many African countries have now come to appreciate that, despite the fact that tax treaties can be restrictive, there are benefits that result from entering into tax treaties in that they can encourage and facilitate capital inflows from capital-exporting countries (Thuronyi 1998). This, however, puts African countries in a position whereby, in the absence of measures that counter tax avoidance, the

\footnotetext{
29

Rodrik (2015), where he states that 'so-called "frontier market economies" are the latest fad in investment circles. Though these low-income countries - including Bangladesh and Vietnam in Asia, Honduras and Bolivia in Latin America, and Kenya and Ghana in Africa - have small, undeveloped financial markets, they are growing rapidly and are expected to become the emerging economies of the future'.
} 
treaties entered into can be abused, resulting in BEPS. This is a major concern, since the tax laws of most African countries are often not sufficiently developed to prevent BEPS arising from the abuse of tax treaties (Thuronyi 1998). Treaty abuse is also exacerbated when countries negotiate treaty provisions that are not in their favour, but rather reflect the position of the other contracting state (Akunobela 2012). The ability to negotiate favourable provisions depends a lot on the treaty-negotiating power of the relevant country. In general, developed countries are better skilled in negotiating tax treaties than developing countries (PwC 2011). The UN notes that:

Developing countries, especially the least developed ones, often lack the necessary expertise and experience to efficiently interpret and administer tax treaties. This may result in difficult, time-consuming and, in a worst case scenario, ineffective application of tax treaties. Moreover, skills gaps in the interpretation and administration of existing tax treaties may jeopardise developing countries' capacity to be effective treaty partners, especially as it relates to cooperation in combating international tax evasion. There is a clear need for capacity-building initiatives, which would strengthen the skills of the relevant officials in developing countries in the tax area and, thus, contribute to further developing their role in supporting the global efforts aimed at improving the investment climate and effectively curbing international tax evasion (United Nations 2013 iii).

Negotiating tax treaties requires knowledge of international tax law and tax treaty principles, as well as taxing authorities having a certain level of technical knowledge. The challenge for most developing countries is the lack of administrative capacity to negotiate tax treaties (Thuronyi 1998). When residents of the other contracting state conduct business in the developing country and, on the basis of that treaty, pay nil or minimum taxes in the source state, disputes often arise due to a lack of understanding of what was signed for. For tax officials not conversant with tax treaty issues, it is important to emphasise that generally treaties do not impose tax - rather they limit the taxes that can be imposed by the contracting states (Olivier and Honiball 2011). A treaty cannot impose tax where the income is not subject to tax under domestic legislation (Olivier and Honiball 2011). It is very important to understand this, as loss of taxes often arises due to a perception that the relevant transaction ought to have been taxed, whereas domestic law does not provide for its taxation.

\subsection{Limited tax administrative capacity}

Many African countries have limited capacity to implement solutions to curtail BEPS. It is acknowledged that African tax systems are not homogenous, and that both the level of economic development of African countries and the level of capacity to deal with the challenges associated with BEPS vary immensely (G20 2014). To curtail BEPS, African counties need to revamp their administrative capacity. This entails employing competent tax officials in various fields, such as accountants, lawyers and economists, who can understand and administer complex international tax laws. Continuous training is required for such officials to ensure they are up-to-date with current international developments. For African governments to hire and retain specialised tax officials, they need to adopt policies which ensure that these officials are paid salaries comparable to those in the private sector. Administrative capacity also requires training such officials in technical expertise to carry out tax audits. This requires electronic and technological advancement of tax systems, so as to handle BEPS issues such as those relating to automatic exchange of information in tax matters. Measures to improve the competency of tax officials have to be combined with measures to ensure their integrity, as this is key to enhancing revenue collection. The large discretionary powers given to tax authorities often encourage corruption, which must be rooted out. 
These matters are already recognised in a number of countries, which have begun introducing reform programmes. These include Ethiopia, which is working on enhancing the capacity of the revenue authority - a central part of Ethiopia's public sector reform programme; Cameroon, which introduced administrative reforms in 2004 followed by the 2007 Fiscal Reform Commission; Tanzania, which introduced reforms to strengthen tax administration to curtail extensive loopholes and rampant corruption; and Rwanda, which, as a result of recommendations by the IMF, introduced tax policy reform measures from 2010 (Culpeper and Bhushan 2010).

\section{The relevance of the OECD BEPS project to Africa}

The OECD 2013 BEPS Action Plan notes that, in order to ensure international consensus in addressing BEPS, it would take into account the perspectives of developing countries (OECD 2013b). However criticism has been raised that the OECD agenda has been driven by the interests of developed countries and that the interests of developing countries are not being addressed, since they were not consulted to table their concerns before the OECD 15Point Action agenda was drafted and closed. The OECD's initial regional consultations only served as orientation to a pre-existing plan. This fell short of global equal participation in the formulation of the international tax reforms. The BEPS Action agenda is criticised for embodying rules set by a few countries, and thereby reinforcing a system that exacerbates global inequality. ${ }^{30}$ The BEPS Action Plan portrays a lack of focus or understanding of the specific need of developing countries.

The OECD's approach has also been criticised for not addressing basic fundamental international tax reform, or re-examining the basic principles of the international tax system that are pivotal in addressing BEPS - such as the allocation of tax income between residence and source countries. The OECD chose to focus on curtailing sophisticated tax avoidance schemes by strengthening existing anti-avoidance provisions, to ensure that they are more effective in curtailing BEPS under modern business models. However, since taxpayers have manipulated these very anti-avoidance provisions to a point of being ineffective, there is little reason to expect that strengthening the rules further will prevent BEPS. Some advanced tax avoidance practices may have been ignored. It has thus been postulated that the OECD's BEPS Action Agenda is a reactionary approach to meet revenue demands by European countries to cover their budgetary deficits after the 2007/2008 global financial crisis. This left many of them in a position of capital importers, and they are now disadvantaged by the international tax rules that were crafted to suit them. Now that damaging effects have been felt by rich countries, they have found the political will to look for solutions to the problems that developing countries have been struggling with for decades. Criticism has also been raised about the ambitious two-year period that the OECD gave for countries to address the 15-Point BEPS Action Agenda, without consideration of the administrative, economic and systemic challenges that many developing countries face.

$30 \quad$ Francophone LIC Finance Ministers Network, Press Note, 'LIC Ministers Demand Their Fair Share of Global Tax Revenues' (9 October 2014, Washington DC). The Press Note states Finance Francophone LICs 'require a more fundamental reform of the international tax system in order to get their fair share of global tax revenues ... current G20/OECD initiatives against tax avoidance and evasion are not tackling the key practices which most reduce LIC revenues ...The cause of these problems is the lack of decision making power for LICs in global tax discussions. Consultation by the IMF and OECD cannot be sufficient: LICs need an equal seat at the table'. 


\section{How should Africa respond to the OECD BEPS Action Plan?}

No African country is a member of the OECD, and African countries are not bound to follow the OECD recommendations. Although the primary focus of the OECD is on its member countries, its additional goals of contributing to the expansion of world trade and the development of the world economy affect non-members as well. ${ }^{31}$ It would, therefore, be in the interest of African countries to respond to the OECD recommendations, since BEPS is a global challenge that requires global solutions. All countries (including African economies) have a shared interest in strengthening the integrity of the international corporate tax system. Given that many African countries have large resource bases that are exploited by foreign investors, it is important that they take proactive steps to prevent BEPS (G20 2014).

It is also important to note that, despite all the above criticism of the OECD BEPS agenda, internationally there has been a shift in the philosophy of some governments that encouraged the perpetuation of certain notorious tax avoidance schemes. For example, the Irish government has taken measures to close tax loopholes that permit the use of the 'double Irish sandwich' scheme, which allowed companies registered in Ireland to be stateless and thus tax pay nowhere (IDS 2014). Switzerland has signed the Multinational Convention on Mutual Assistance in Tax Matters, thereby committing to cooperating with other governments on exchanging information on tax matters (IDS 2014). The will to address BEPS is not only there at a governmental and international level, but MNEs also appear to have pulled back on aggressive tax avoidance due to increasing concern about reputational risks as a result of controversies in the UK over tax arrangements of MNEs such as Starbucks, Amazon and Google. Tax avoidance and resultant reputational risks are now a topic of discussion in company Board meetings.

With the current global stance on BEPS, African countries should not be passive to the OECD BEPS Action Plan: they should make use of this opportunity to ensure that their longstanding BEPS concerns are addressed while the international political will and support of the international community still stands. African countries should use the current international political will to address BEPS, and get together under regional organisations such as the African Tax Administration Forum (ATAF - which promotes and facilitates mutual cooperation among African tax administrators), to develop a united position on those BEPS priority concerns that are relevant for them. African countries should ensure they present their views on the different OECD discussion drafts of the various Action Plans. Currently comments on these discussion drafts are largely from representatives of big business and lobbyists from the tax avoidance industry. Civil society, mainly in developed countries, has also provided detailed and constructive comments on all the discussion drafts, but there has not been much comment from African countries. There is a need for a stronger voice from Africa, and more civic education on fiscal matters. The OECD has, however, engaged extensively with developing countries that have have participated directly in the technical working groups and indirectly through regional consultations where they have shaped the outcomes of the BEPS Project. In November 2014 the OECD launched a new strategy for deepening developing countries' engagement in the BEPS Project (OECD 2014a). In 2016, the OECD launched an inclusive framework for BEPS implementation on an equal footing for all countries that commit to the process (OECD 2016).

This is important for achieving principled and sustainable reforms to lay a foundation for international tax rules suited for the twenty-first century. African countries must call on all stakeholders, such as the G20 countries, international and regional organisations, civil

$31 \quad$ See OECD (n.d.). 
society and donors, to raise awareness of the significance of BEPS issues in Africa by holding high-level political dialogue on these issues with Ministries of Finance and other relevant ministries (G20 2014). African countries need to change the impression that has been created that they are instruction-takers not decision-makers.

\section{Initiatives in Africa responding to the OECD BEPS agenda}

\subsection{Initiatives by regional bodies}

In March 2014, AFAF held a conference in Johannesburg on the Global Tax Agenda for heads of African tax administrations and Ministries of Finance. Participants from twenty-nine African countries and OECD officials deliberated on the 'New Rules of the Global Tax Agenda' and the G20/OECD-driven project on BEPS, and considered an African response to these developments. In its Conference Outcomes Document, ATAF noted that the development of rules for global taxation should address the concerns of all countries and that it should be inclusive, to ensure that the international tax rules can be applied effectively by developed, emerging and developing countries (ATAF 2014). In this regard, ATAF notes that it is imperative that all African countries are involved in the BEPS process. Africa must use the opportunity to shape the issues in the 15 Action Point project to address Africa's concerns, to ensure that sufficient attention is given to the different levels of readiness of African tax administrations to address BEPS, and their resource and capacity limitations (ATAF 2014). ATAF notes that much needs to be done to improve administrative capacity, broaden the tax base, and increase tax revenue in Africa as a proportion of GDP (ATAF 2014). Consequently it made a commitment to facilitate African participation in the Global Tax Agenda, and to put in place structures to enable on-going dialogue about BEPS on the continent and internationally. This would ensure that African countries understand the G20/OECD processes, and can engage with these countries more productively (ATAF 2014). To this end, ATAF developed an African Work Plan on the Global Tax Agenda, for which a 'Cross-Border Taxation Technical Committee' was established to provide guidance on an African BEPS approach and to give input into the OECD BEPS process. ${ }^{32}$ ATAF recognises that Africa needs to re-examine its own regional tax cooperation and practices, and develop an approach on how the continent will engage with the rest of the world on these matters. It has therefore called on African countries to strengthen their support and commitment to ATAF, as this will allow ATAF greater impact in engaging with the OECD (ATAF 2014).

Following its 2014 consultative conference on 'New Rules of the Global Tax Agenda', ATAF convened another conference on 'Cross-Border Taxation in Africa' in April 2015 in Johannesburg. The conference focused on an African position on the BEPS Action Points, and on providing African countries an opportunity to define the base-eroding practises that are most relevant to Africa. Speaking at this conference, South Africa's Minister of Finance reiterated that it is critical that African countries use all opportunities to make inputs into the BEPS project to ensure that the views and experiences of African countries shape the development of potential BEPS-related solutions, and that African countries should ensure that any redefinition of the international tax rules should take into consideration the needs and conditions of the African continent. Further, that 'Africa must protect its own tax base and advance domestic resource mobilisation through a common voice, a common concern and a common action plan.' The Minister remarked that the current global focus on international taxation offers a unique opportunity for African leaders to embark on their own continental

32 ATAF Secretariat 'Ist Meeting Cross-Border Technical Committee' (21-22 November 2014). 
taxation renaissance: this should include giving consideration to the establishment of a Tax Policy and Tax Administration Commission, which is missing within the structures of the African Union. Such a Commission would deal with harmonising the continent's tax policy, legislation and administration, as well as seeking ways to improve cross-border cooperation and thereby optimising continental revenue mobilisation. In this regard, ATAF has indicated that it intends to formalise its engagement with the African Union at ministerial level, as it is of the view that the involvement of African Heads of State in the implementation of agreed proposals contemplated in the OECD BEPS process is critical to resolving BEPS in Africa. ${ }^{33}$

\subsection{BEPS initiatives at national level}

Efforts to address BEPS in Africa have also been made at national level. In this regard, South Africa appears to have taken the lead. In July 2013, South Africa's then Minister of Finance appointed a tax review committee (the Davis Tax Committee) to inquire into the role of South Africa's tax system in the promotion of inclusive economic growth, employment creation, development and fiscal sustainability. ${ }^{34}$ On the international front the Committee is required to address concerns about BEPS, especially in the context of corporate income tax, as identified by the OECD and G20. In December 2014, the Davis Tax Committee released its first BEPS Interim Report for public comment. African countries are looking to South Africa for guidance on how to move forward on these issues, and they are keenly following the work of the Davis Tax Committee. The outcome of the work of the Davis Tax Committee is therefore of critical importance for regional and continental integration.

At the November 2013 conference on 'The G-20 and Africa's Economic Growth and Transformation', South Africa's then Minister of Finance stated that the South African Revenue Service (SARS) aims to ensure companies and wealthy individuals pay their fair share of taxes (Kotch 2013). The Minister noted that SARS was dealing with several cases of BEPS which impact on billions of rand of tax which is payable to South Africa, and that SARS had picked up a number of cases of high net worth individuals who are not paying their fair share. The Minister further remarked that South Africa was taking a front-row position in global tax reforms (Kotch 2013).

Although South Africa is not a member of the OECD, it was awarded OECD observer status in 2004 (Olivier and Honiball 2011), and is a member of the OECD BEPS Committee. South Africa is also the only African country that is a member of the G20. This does not mean that South Africa's membership to these international bodies is representative of the interests of African countries. Nevertheless, as a major economic power on the African continent, it is important that South Africa champions the cause of Africa in the OECD BEPS Committee. As a member of the G20 Development Working Group, South Africa plays an important role in conveying the views of developing economies in Africa (G20 2014).

\footnotetext{
33 Minister Nhlanhla Nene: African Tax Administration Forum Conference on Cross Border Taxation in Africa (21 April 2015). Available at <http://www.gov.za/speeches/page-1-11-speech-minister-finance-mr-nhlanhla-nene-atafconference-cross-border-taxation>, accessed 28 April 2015.

34 The Davis Tax Committee 'Introduction', available at <http://www.taxcom.org.za/>, accessed 12 May 2015.
} 


\section{International initiatives that African countries should embrace to improve their tax systems and administrative capacity}

\subsection{OECD initiatives on BEPS that can benefit Africa}

Although the OECD's main concern is its member countries, following the rise of emerging economies like the BRICS countries over the last decade the OECD has tried to involve developing countries in issues relating to tax treaties and international tax laws. ${ }^{35}$ It has, for instance, invited developing countries to serve as observers to some of its meetings. South Africa was awarded OECD observer status in 2004. The OECD has also selected some developing countries to register objections to positions taken by the OECD on its Commentary to its Model Tax Convention. However, these initiatives are unlikely to result in developing countries influencing the core decisions taken by the OECD on tax matters, or other matters that OECD countries may take a strong position on (Mclntyre 2015). With respect to BEPS in developing countries, the OECD has made a commitment to support developing country revenue authorities (OECD 2014b). It has, for instance, pledged to help in funding capacity development in African tax authorities through initiatives like 'Tax Inspectors without Borders': African countries should take advantage of this. ${ }^{36}$ This initiative enables the transfer of tax audit knowledge and skills to tax administrations in developing countries through a 'learning by doing' approach. Tax officials, who may be currently serving or recently retired, are deployed to work directly with local tax officials on audits concerning international tax matters, and to share general audit practices. ${ }^{37}$

\subsection{G20 initiatives on BEPS in Africa}

The G20 acknowledges that many developing countries have limited capacity to implement global BEPS solutions, and that this will affect their ability to reap the full benefits of international tax reforms (G20 2014). The G20 countries have pledged to work with developing countries to help them build effective tax systems, so as to enforce BEPS rules and to effectively use tax data (e.g. audit capacity) to ensure compliance with international standards and norms. The G20 also recognises that the economic development of African countries varies immensely, as does the level of development of their tax laws and their administrative capacity to deal with the challenges associated with implementing international tax reforms (G20 2014). Thus an assessment of how to strengthen tax systems must be done on a case-by-case basis. The G20 recognises that developing economies need regular, proactive engagement in the G20/OECD BEPS process, particularly for those countries that may be harder to reach due to geography, capacity, size, or other reasons that may impact upon their ability to effectively implement and benefit from the outcomes of the BEPS Action Plan (G20 2014). Such countries may require tailored approaches to implement the outcomes of the BEPS Action Plan, without undermining the integrity of the international tax system. African countries in which the G20 reported activity are: Tanzania, Kenya, Uganda, Rwanda and Ethiopia (G20 2014). In these countries measures have been taken to provide support for capacity development, with a focus on shaping the fundamental building blocks of tax policy and administration to ensure that these economies can reap the full

\footnotetext{
$35 \quad$ BRICS stands for five emerging economies (Brazil, Russia, India, China and South Africa). These countries are considered to be in a similar stage of newly advanced economic development, and are the leading emerging economies in the $21^{\text {st }}$ century.

36 OECD 'Tax Inspectors Without Borders', available at <http://www.oecd.org/tax/taxinspectors.htm>, accessed 7 July 2015. Ibid.
} 
benefits of international tax reforms and mobilise domestic resources for development. In particular, G20 members have made a commitment to make available tax policy and administration experts on a voluntary basis, based on the resource needs of the relevant countries.

The G20 Development Working Group on BEPS has been actively involved in Africa, partnering with regional tax and economic organisations such as ATAF, the African Organisation of English-speaking Supreme Audit Institutions, the East African Community, the Economic Community of West African States, and the West African Economic and Monetary Union (G20 2014). G20 members have committed to take practical steps to support regional tax administration forums in fulfilling their role as a bridge between the international tax agenda and developing economies, by facilitating capacity-building though providing financial or in-kind support, and participating in an advisory or knowledge-sharing capacity. The G20 has also called on the OECD, IMF, UN and the World Bank Group to work together and with regional tax administration forums to come up with practical toolkits to assist developing economies to implement BEPS action items as appropriate, depending on the outcome of each BEPS action item. The toolkits are to be coordinated and developed over the course of 2015 and 2016, depending on when the relevant action items are completed, and are intended to prioritise action items that have the greatest impact for developing economies (G20 2014).

\subsection{UN initiatives on BEPS}

The UN has historically championed the cause of developing countries in international tax issues. Its work on international tax matters has been carried out by an Ad Hoc Group of Experts on Tax Treaties between Developed and Developing Countries, formed in 1968, comprising tax experts and officials from twenty countries acting in their individual capacity (Mclntyre 2015). It was the work of this Ad Hoc Group of Experts that in 1980 culminated in the UN Model Double Taxation Convention between Developed and Developing Countries, which is in favour of source countries. However the effectiveness of the UN's work in this regard has been hampered due to underfunding. As a result of the Monterrey International Conference on Financing for Development, which called for strengthening international tax cooperation through enhanced dialogue among tax authorities and for special attention to be given to the needs of developing countries and those in transition, in November 2004 the UN's Economic and Social Council elevated the UN Ad Hoc Group of Experts on International Cooperation in Tax Matters to the status of a permanent UN Committee. This change in status is likely to increase the voice of developing countries in international forums dealing with tax issues (Mclntyre 2015). At the subsequent 2008 Doha Declaration on Financing for Development, Heads of State deliberated on whether to upgrade the UN Committee to governmental status or to provide more funding for it. In the Outcome Document of the UN's 'Third International Conference on Financing for Development' held in Addis Ababa 13-16 July 2015, the Heads of State and Government and High Representatives welcomed the work of the Committee of Experts on International Cooperation in Tax Matters, and decided to enhance its resources in order to strengthen its effectiveness and operational capacity (United Nations 2015). To that end, they increased the frequency of its meetings to two four-day sessions per year. Member states were urged to support the Committee through the voluntary trust fund, to enable the Committee to fulfil its mandate, including supporting the increased participation of developing country experts at sub-committee meetings (United Nations 2015).

The UN participates in the tax work of the OECD to provide insights regarding the particular concerns of developing countries. Commenting on the causes of BEPS, the UN notes that historically countries have viewed the development of domestic international tax laws as a matter for each sovereign state. In making these decisions too often little or no account is taken of either the impact their laws have on other countries, or the impact that the laws of 
other countries have on them. ${ }^{38}$ However the tax laws and policies of one country can adversely affect another country's ability to collect the tax that should be due to it. This can be an unintended effect, but whether it is intended or not it has a budgetary effect on the country losing tax revenue, thus impeding its economic development. If some countries do not tax their own multinationals effectively, this gives these multinationals an incentive to shift profits or minimise their taxable presence in other countries where they operate. In the same way, if countries do not tax businesses operating in their jurisdiction in an effective manner, this creates an incentive for multinationals to escape taxation in the country where they are headquartered. ${ }^{39}$

The UN acknowledges that although developing countries face the same issues relating to BEPS as developed countries, the issues may manifest differently given the specificities of their legal and administrative framework (OECD 2013b). The UN has stressed that "efforts in international tax cooperation should be universal in approach and scope and should fully take into account the different needs and capacities of all countries, in particular least developed countries, landlocked developing countries, small island developing states and African countries' (United Nations 2015: para 28). The UN supports the efforts of those such as the OECD 'Tax Inspectors without Borders', and it recognised the need for technical assistance through multilateral, regional, bilateral and South-South cooperation, based on different needs of countries (United Nations 2015).

In October 2013, the UN Committee of Experts on International Cooperation in Tax Matters established a sub-committee on BEPS issues for developing countries. ${ }^{40}$ The mandate of the sub-committee is to monitor developments on BEPS, communicate them to officials in developing countries, and ensure their views are fed into the OECD/G20 BEPS project and on-going UN tax cooperation work. In 2014, the UN sub-committee released a questionnaire asking developing countries to provide feedback on their experience of BEPS and their priority BEPS concerns. ${ }^{41}$ Developing countries that made submissions are Brazil, Chile, China, India, Malaysia, Mexico, Singapore, Bangladesh, Thailand and Tonga; and from Africa - only South Africa, Ghana, Lesotho and Zambia. Responses were also received from NGOs: Christian Aid, ActionAid, the Economic Justice Network and Oxfam South Africa (UN 2014; Peters 2015). It is important that the UN is funded to fully carry out its mandate.

\section{Addressing the OECD BEPS Action Plan from an African perspective}

Although the OECD BEPS Action Plan may have been well-intentioned, as explained above it was not drawn up jointly with developing countries and so does not address their immediate BEPS concerns. Even though BEPS is a global concern, the nature of BEPS concerns is not uniform for all countries. Certain BEPS schemes that work to undermine the European or American tax base often do not coincide with the African paradigm. The BEPS challenges that African (mainly capital-importing) countries face may be different in nature and scale from those faced by developed (mainly capital-exporting) countries (UN 2014; Peters 2015). The development of most African countries' international tax laws still lags behind those of developed countries, and many of them have low administrative capacity, so

\footnotetext{
UN Sub-committee 'Base Erosion and Profit Shifting Issues for Developing Countries', available at $<\mathrm{http}: / /$ www.un.org/esa/ffd/tax/BEPS_note.pdf>, accessed 5 May 2016. 
most of the OECD 15-point Action Plan will most likely benefit African countries in the long term, as and when their economies and administrative capacity advances. It should also be noted that the BEPS project does not explore certain practical measures (such as withholding taxes) that may be more suitable for African countries in addressing BEPS. The G20 Development Working Group on Domestic Resource Mobilisation for developing countries notes that, due to the specific challenges faced by developing countries, the Actions that have the greatest impact for developing economies are:

- Action 4: Limit base erosion via interest deductions and other financial payments;

- Action 6: Prevent treaty abuse;

- Action 7: Prevent the artificial avoidance of PE status;

- Action 10: Assure that transfer pricing outcomes are in line with value creation with respect to other high-risk transactions;

- Action 12: Require taxpayers to disclose their aggressive tax planning arrangements;

- Action 13: Re-examine transfer pricing documentation.

(G20 2014)

Even then, these Action Plans are not necessarily a top priority in all African countries, since they are at different levels of economic development and administrative capacity. From the response to its questionnaire about priority BEPS concerns of developing countries, the above priority concerns are largely the same as those identified by the UN Subcommittee of BEPS (UN 2014).

The ATAF Cross-Border Taxation Technical Committee, created in 2014 to define the African position on BEPS, holds the view that, the OECD BEPS process notwithstanding, Africa must come up with customised solutions to protect its own tax base, to assist African countries and groups of countries in similar positions to ensure domestic resource mobilisation. This is especially so because Africa is fast becoming the investment destination of choice, and its economic growth is set to be even faster over the medium term (ATAF 2014). In Part 2 of this paper on BEPS in Africa, this author adopts this customised approach in discussing three of the BEPS Actions that are of priority to African countries:

- Action 4: Limit base erosion via interest deductions and other financial payments;

- Action 6: Prevent treaty abuse;

- Action 7: Prevent the artificial avoidance of PE status.

\section{Concluding remarks}

Part 1 of this paper on BEPS in Africa has emphasised that the development of rules for global taxation should address the concerns of all countries: all countries must participate equally in the formulation of international tax reforms. The rules should be inclusive, to ensure they are applied effectively by developed, emerging and developing countries. If the reform rules are set by a few countries, this will reinforce a system that exacerbates global inequality. International cooperation is required to address BEPS. Countries should not look out for their own interests, because this will inadvertently result in double non-taxation.

Since BEPS is a global concern, African countries should associate themselves with the OECD recommendations to address BEPS. They have a lot to lose in an ineffective international corporate tax system, since a large proportion of their tax revenue is from taxing MNEs that have invested in their countries. A strong voice from Africa from both government and civil society is needed to comment on BEPS Action items from Africa's perspective. It is important that African countries get together under regional bodies such as ATAF to participate in the OECD BEPS project, and use the opportunity to shape the issues in the 15- 
point Action Plan items to address Africa's concerns. It is also imperative that African countries take advantage of initiatives by international organisations such as the UN, OECD and G20 to increase capacity in their tax administrations, and to help them build effective tax systems so that they can reap the full benefit of international tax reforms. 


\section{References}

ActionAid (2012) Calling Time: Why SABMiller should stop dodging taxes in Africa, available at

$<$ https://www.actionaid.org.uk/sites/default/files/doc_lib/calling_time_on_tax_avoidance .pdf>, accessed 22 June 2015

African Development Bank and Global Financial Integrity (2013) Illicit Financial Flows and the Problem of Net Resource Transfers from Africa: 1980-2009, African Development Bank (Tunisia) and Global Financial Integrity (Washington DC)

Akunobela, F. (2012) 'The Relevance of the OECD and UN Model Conventions and their Commentaries for the interpretation of Ugandan Tax Treaties' in M. Lang, P. Pistone, J. Schuch and C. Staringer (eds) The Impact of the OECD and UN Model Tax Conventions onBilateral Tax Treaties, Cambridge University Press

ATAF (n.d.) 'Twenty One African Countries Finalise Mutual Agreement in Collecting Taxes', available at <http://www.ataftax.net/news/ataf-in-the-media/twenty-one-africancountries-finalise-mut... accessed 26 June 2015

(2014) Outcomes Document: Consultative Conference on New Rules of the Global Tax Agenda, Johannesburg, South Africa: 18-19 March 2014, available at $<\mathrm{http}: / / w w w . s l i d e s h a r e . n e t / D r L e n d y S p i r e s F o u n d a t i o n / o u t c o m e s-a t a f-c o n s u l t a t i v e-$ conference-on-new-rules-of-the-global-tax-agenda>, accessed 28 April 2015

Australian Government (1999) Final Report of the Review of Business Taxation: A System Redesigned, The Treasury, Australian Government

Avi-Yonah, R. (2015) Hanging Together: A Multilateral Approach To Taxing Multinationals, U of Michigan Public Law Research Paper No. 364, U of Michigan Law and Econ Research Paper No. 15-012, available at <http://ssrn.com/abstract=2344760>, accessed 24 May 2015

Baker, R. (2005) Capitalism's Achilles Heel: Dirty Money and How to Renew the Free-Market System, John Wiley \& Sons

Bennet, T. (2001) International Initiatives Affecting Financial Havens, London: LexisNexis

Bratton, W. and McCahery, J. (2001) "Tax Coordination and Tax Competition in the European Union: Evaluating the Code of Conduct on Business Taxation', Common Market Law Review 28: 677

Brooks, M. and Head, J. (1997) 'Tax Avoidance: In Economics, Law and Public Choice', in G. Cooper, Tax Avoidance and the Rule of Law, The Netherlands: IBFD Publications

Centre for Strategic and International Studies (2014) Paying for Development: Domestic Resource Mobilization, available at <http://csis.org/publication/paying-developmentdomestic-resource-mobilization>, accessed 3 December 2014

Christian Aid (2008) Death and Taxes: The True Toll of Tax Dodging, available at $<$ http://www.christianaid.org.uk/images/deathandtaxes.pdf> accessed 28 September 2010 
Corey, C. (2008) 'Africa is the New Frontier of Global Economy' (8 October 2008), available at <http://www.america.gov/st/econ-

english/2008/October/20081010111004WCyeroC0.1286432.html>, accessed 7 June 2014

Crivelli, E., de Mooij, R. and Keen, M. (2015), Base Erosion, Profit Shifting and Developing Countries, IMF working paper WP/15/118

Culpeper, R. and Bhushan. A. (2010) 'Why enhance domestic resource mobilisation in Africa?', Trade Negotiation Insights 9(6), available at <http://www.ictsd.org/bridgesnews/trade-negotiations-insights/news/why-enhance-domestic-resource-mobilisationin-africa>, accessed 3 December 2014

Diamond, W. and Diamond, D. (2002) Tax Havens of the World, Newark NJ: Matthew Bender

Durst, M. (2014) Beyond BEPS: A Tax Policy Agenda for Developing Countries, ICTD Working Paper 18, Brighton: International Centre for Tax and Development

Fuest, C. and Riedel, N. (2010) Tax Evasion and Tax Avoidance in Developing Countries: The Role of International Profit Shifting, Oxford University Centre for Business Taxation Working Paper 10/12

—_ Spengel, C., Finke, K., Heckemeyer, J. and Nusser, H. (2013) Profit Shifting and Aggressive Tax Planning by Multinational Firms: Issues and Options for Reform, Oxford University Centre for Business Taxation Discussion Paper No. 13-078

G20 (2014) G20 Response to 2014 Reports on Base Erosion and Profit Shifting and Automatic Exchange of Information for developing Countries, Development Working Group on Domestic Resource Mobilisation, available at <https://g20.org/wpcontent/uploads/2014/12/16\%20G20\%20response\%20to\%202014\%20reports\%20on\% 20BEPS\%20and\%20AEOI\%20for\%20developing\%20economies.pdf>, accessed 4 March 2015

Global Financial Integrity (2014a) 'GFI Welcomes New US-Africa Partnership to Combat Illicit Finance' (6 August 2014)

_ (2014b) Illicit Financial Flows for Developing Countries between 2003 and 2012 (16 December 2014)

IDS (2014) Will Changes to the International Tax System Benefit Low-Income Countries, Rapid Response Briefing Issue 06, Institute of Development Studies, January 2014

IMF (2014) Spillovers in International Corporate Taxation, available at <www.imf.org/external/np/pp/eng/2014/050914.pdf>

Kar, D. and Cartwright-Smith, D. (2008) Illicit Financial Flows from Developing Countries: 2002-2006, Washington DC: Global Financial Integrity, <http://www.gfip.org/index.php?option=content\&tas k=view\&id=274>, accessed 6 March 2015

and Spanjers, J. (2014) Illicit Financial Flows from Developing Countries: 2003-2012, Global Financial Integrity, available at <http://www.gfintegrity.org/wp- 
content/uploads/2014/12/Illicit-Financial-Flows-from-Developing-Countries-20032012.pdf accessed 22 June 2015>

Kesti, J. (2013) European Tax Handbook, IBFD

Kotch, N. (2013) 'South Africa Aims To Lead in Closing Tax Loopholes', BusinessDay, available at <http://www.bdlive.co.za/africa/africanbusiness/2013/11/12/south-africaaims-to-lead-in-closing-tax-loopholes>, accessed 12 November 2013

McIntyre, M. (2015) Developing Countries and International Cooperation on Income Tax Matters: A Historical View, available at <http://www.michielse.com/files/mcintyre_intl_cooperation.pdf>, accessed 6 May 2016

McKibbin, W. (2010) The Global Financial Crisis: Causes and Consequences, 9 Asian Economic Papers, pp. 54-86 (2010).

Meyerowitz, D. (2009) Meyerowitz on Income Tax,Cape Town: Taxpayer CC

Ndikumana, L. and Boyce, J. (2010) 'Measurement of Capital Flight: Methodology and Results for Sub-Saharan African Countries', African Development Review, 22(4): 471 481

North-South Institute (2012) Domestic Resource Mobilisation in Africa: An Overview, available at <http://www.nsi-ins.ca/wp-content/uploads/2012/10/2010-DomesticResource-Mobilization-in-Africa-An-Overview.pdf>, accessed 3 December 2014

OECD (n.d.) History of the OECD, available at <http://www.oecd.org/document/63/0,2340,and_2649_201185_1876671_1_1_1_1,00.h tml>, accessed 20 November 2014

OECD (2016) Inclusive Framework For BEPS Implementation, available at $<$ https://www.oecd.org/tax/background-brief-inclusive-framework-for-bepsimplementation.pdf>, accessed 18 May 2016

OECD (2014a) The BEPS Project and Developing Countries: from Consultation to Participation, available at <http://www.oecd.org/ctp/strategy-deepening-developingcountry-engagement.pdf>, accessed 18 May 2016

_ (2014b) Strategy for Deepening Developing Country Engagement in the BEPS Project, available at <www.oecd.org/ctp/strategy-deepeningdeveloping-countryengagement.pdf>, accessed 9 July 2015

(2013a) Addressing Base Erosion and Profit Shifting, Paris: OECD Publishing (2013b) Action Plan on Base Erosion and Profit Shifting, Paris: OECD Publishing (2007a) Tax Co-operation Towards a Level Playing Field: 2007 Assessment by the Global Forum on Taxation, available at <www.oecd.org/document/29/0,3343,fr_2649_201185_39473821_1_1_1_1,00.html>, accessed 9 April 2015

— (2007b) Fundamental Reform of Corporate Income Tax, Paris: OECD Publishing 
— (1998) Harmful Tax Competition, Paris: OECD Publishing

— (1987) Issues in International Taxation No 1 International Tax Avoidance and Evasion (Four Related Studies), Paris: OECD Publishing

Olivier, L. (1997) 'Tax Avoidance Options Available to the Commissioner for Inland Revenue', 4 South African Law Journal

and Honiball, M. (2011) International Tax: A South African Perspective, Siber Ink

Oxford University Centre for Business Taxation (2012) The Tax Gap for Corporation Tax, Paper 3, commissioned by the National Audit Office, available at $<$ http://www.sbs.ox.ac.uk/sites/default/files/Business_Taxation/Docs/Publications/Repo rts/TaxGap_3_12_12.pdf>, accessed 15 June 2015

PWC (2011), Implementing the Tax and Development Policy Agenda: Final Report on Transfer Pricing and Developing Countries, EuropeAID

Payne, R., Rowe, G., Bolger, F.and Shubert, E. (2014) Policy Options for Addressing Illicit Financial Flows: Results from a Delphi Study, Academics Stand Against Poverty

Peters, C. (2015) 'Developing Countries' Reactions to the G20/OECD Action Plan on Base Erosion and Profit Shifting' Bulletin For International Taxation (June/July 2015)

Rapakko, A. (1989) Base Company Taxation, Deventer Boston: Kluwer Law and Taxation Publishers

Rodrik, D. (2015) 'Global Capital Heads for the Frontier', available at <http://www.projectsyndicate.org/commentary/frontier-market-economy-fad-by-dani-rodrik-201503\#mPMikAToAiogq8md.99>, accessed 18 May 2015

Roper, P. and Ware, J. (2000) Offshore Pitfalls, Durban: Butterworths

Santiso, J. (2007) Africa: A New Frontier for Emerging Markets,(December 2007), OECD Development Centre Policy Insight No. 55, available at <http://www.oecd.org/dataoecd/58/22/39733178.pdf>, accessed 7 June 2015

Shah, A. (2010) 'Global Financial Crisis' 28 Global Issues (November 2010), available at $<$ www.globalissues.org/article/768/global-financial-crisis> accessed 24 June 2014

Spitz, B. and Clarke, G. (2002) Offshore Service, London: Butterworths

Stikeman, E. (2002) Towards a Level Playing Field: Regulating Corporate Vehicles in Cross Border Transactions, London: Stikeman Elliot

Tax Justice Network (n.d.) Economic Crisis + Offshore, available at <http://www.taxjustice.net/cms/front_content.php?idcat=136>, accessed 6 June 2015

Terra, B. and Wattel, P. (2005) European Tax Law 4 ed, The Hague: Kluwer Law International 
Thabo Mbeki Foundation (n.d.) 'Tackling Illicit Capital Flows for Economic Transformation', available at <http://www.thabombekifoundation.org.za/Pages/Tackling-Illicit-CapitalFlows-for-Economic-Transformation.aspx>, accessed 9 March 2015

Thuronyi, V. (1998) Tax Law Design and Drafting, International Monetary Fund

Times Live (2015) 'Billions of Rands leave SA Under the Radar', available at <http://www.timeslive.co.za/thetimes/2015/01/11/billions-of-rands-leave-sa-under-theradar>, accessed 9 March 2015

UNCTAD (2014) Trade and Development: Global Governance and Policy Space for Development, Geneva: United Nations Publications

(2007) Economic Development in Africa, UNCTAD, Geneva: United Nations Publications

United Nations (2015) Outcome document of the Third International Conference on Financing for Development: Addis Ababa Action Agenda (13 to 16 July 2015), available at <http://www.un.org/ga/search/view_doc.asp?symbol=A/CONF.227/L.1>, accessed 17 August 2015

(2014) Tenth Session of Committee of Experts on International Cooperation in Tax Matters, Responses to questionnaire for developing countries from the UN Subcommittee on Base Erosion and Profit Shifting (31 September 2014), available at $<$ http://www.un.org/esa/ffd/tax/tenthsession/CRP12_BEPS.pdf>, accessed 8 May 2016

(2013) Handbook on Selected Issues in Administration of Double Tax Treaties for Developing Countries, New York: United Nations Publications

(1984) International Cooperation in Tax Matters Guidelines for International Cooperation Against the Evasion and Avoidance of Taxes (With Special Reference to Taxes on Income, Profits, Capital, and Capital Gains), Ad Hoc Group of Experts on International Co-operation in Tax Matters, Department of International Economic and Social Affairs, United Nations New York 


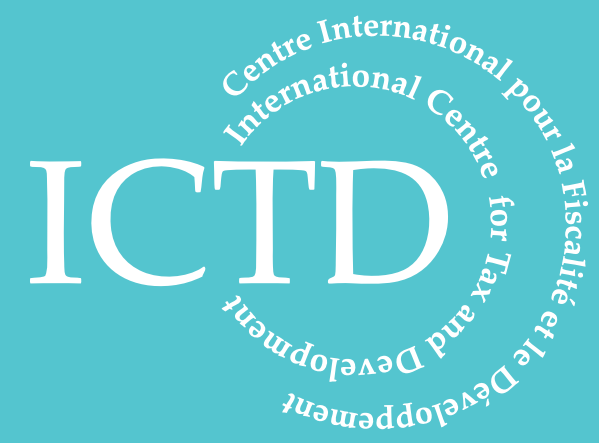

International Centre for Tax and Development at the Institute of Development Studies

Brighton BN1 9RE, UK

T: +44 (0) 1273606261

F: $+44(0) 1273621202$

E: info@ictd.ac

www.ictd.ac 